\title{
A novel application of natural fluorescence to understand the sources and transport pathways of pollutants from livestock farming in small headwater catchments
}

\author{
G.H. Old ${ }^{\text {a,* }}$, P.S. Naden ${ }^{\text {a }}$, S.J. Granger ${ }^{\text {b }}$, G.S. Bilotta ${ }^{\text {c }}$, R.E. Brazier ${ }^{\text {d }}$, C.J.A. Macleod ${ }^{\text {e }}$, T. Krueger ${ }^{\text {f }}$, R. Bol ${ }^{\text {b }}$, \\ J.M.B. Hawkins ${ }^{\text {b }}$, P. Haygarth ${ }^{\mathrm{g}}$, J. Freer ${ }^{\mathrm{h}}$ \\ a Centre for Ecology and Hydrology, Wallingford, Oxfordshire, UK \\ ${ }^{\mathrm{b}}$ North Wyke Research, Okehampton, Devon, UK \\ c School of Environment and Technology, University of Brighton, Brighton, UK \\ d School of Geography, Archaeology and Earth Resources, The University of Exeter, Devon, EX4 4QJ, UK \\ e The James Hutton Institute, Craigiebuckler, Aberdeen, AB15 8QH, UK \\ ${ }^{f}$ School of Environmental Sciences, University of East Anglia, Norwich, NR4 7TJ, UK \\ ${ }^{g}$ Lancaster Environment Centre, The University of Lancaster, Lancaster, LA1 4YQ UK \\ h School of Geographical Sciences, University of Bristol, Bristol, BS8 1SS, UK
}

\section{A R T I C L E I N F O}

\section{Article history:}

Received 8 August 2011

Received in revised form 28 November 2011

Accepted 3 December 2011

Available online 24 January 2012

\section{Keywords:}

Fluorescence

Dissolved organic matter

Agricultural pollution

Tracing pollutants

Headwater stream

Eutrophication

\begin{abstract}
A B S T R A C T
This paper demonstrates the application of a low-cost and rapid natural fluorescence technique for tracing and quantifying the transport of pollutants from livestock farming through a small headwater catchment. Fluorescence intensities of Dissolved Organic Matter (DOM) present in different pollutant sources and drainage waters in the Den Brook catchment (Devon, UK) were monitored through storm events occurring between January 2007 and June 2008. Contrasting fluorescence signals from different sources confirmed the technique's usefulness as a tracer of pollutants from livestock farming. Changes in fluorescence intensities of drainage waters throughout storm events were used to assess the dynamics of key pollutant sources. The farmyard area of the catchment studied was shown to contribute polluted runoff at the onset of storm events in response to only small amounts of rain, when flows in the Den Brook first-order channel were low. The application of slurry to a field within the catchment did not elevate the fluorescence of drainage waters during storm events suggesting that when slurry is applied to undrained fields the fluorescent DOM may become quickly adsorbed onto soil particles and/or immobilised through bacterial breakdown. Fluorescence intensities of drainage waters were successfully combined with discharge data in a two component mixing model to estimate pollutant fluxes from key sources during the January 2007 storm event. The farmyard was shown to be the dominant source of tryptophan-like material, contributing $61-81 \%$ of the total event flux at the catchment outlet. High spatial and temporal resolution measurements of fluorescence, possibly using novel in-situ fluorimeters, may thus have great potential in quickly identifying and quantifying the presence, dynamics and sources of pollutants from livestock farming in catchments.
\end{abstract}

(c) 2011 Elsevier B.V. All rights reserved.

\section{Introduction}

The deleterious impacts of livestock farming on freshwater systems are widely appreciated (Bilotta et al., 2007). Hooda et al. (2000) provide a comprehensive review in which they summarise the main issues as those relating to inputs of (a) nutrients - especially nitrogen and phosphorus (e.g. Levine and Schindler, 1989), (b) organic effluents with high solids content (e.g. Cooper, 1993), (c) pesticides (e.g. Coddington, 1992), and (d) bacterial and protozoan pathogens (e.g. Kay et al., 2008). The impacts of assemblages of these pollutants on river ecosystems are recognised by current legislation (i.e. EU Water Framework

\footnotetext{
* Corresponding author. Tel.: +44 1491 692486; fax: +44 1491692424. E-mail address: gho@ceh.ac.uk (G.H. Old).
}

Directive, European Commission, 2000). Pasture-based livestock farming systems with grazed fields, farmyards, and food/fertiliser storage areas, in particular, are likely to contribute such an assemblage of pollutants to headwater streams.

Although the water quality (chemical, biological, nutrient and aesthetic) of main river sites (flows typically $>1 \mathrm{~m}^{3} \mathrm{~s}^{-1}$ ) and canals have been monitored in the UK since 1988, knowledge on the quality of headwater streams is limited (cf Countryside Survey: Dunbar et al., 2010). These are of vital importance and must now be protected under the Water Framework Directive. In particular, headwater streams may have major impacts on downstream water quality (Bowes et al., 2005; Withers et al., 2009) and represent an important ecological resource (Furse et al., 1991). Pollutant inputs from livestock farming to headwater streams (e.g. Jarvie et al., 2010) can have major local impacts owing to their limited potential for dilution. 
However, Withers et al. (2009) acknowledge that it is often difficult to trace these multiple sources. They explain how current approaches to manage pollutant inputs focus on 'point sources' (i.e. sewage discharges) and 'diffuse sources' (i.e. agricultural land) with little attention being paid to 'intermediate sources' such as farmyards, septic tanks and roads although these may be highly significant (e.g. Jarvie et al., 2010; Neal et al., 2005).

Clay soils on steep slopes in regions of high rainfall in western Britain are often managed intensively for dairy pasture. Potential for delivery of livestock associated pollutants from these areas via point, diffuse and intermediate sources is very high. However, the link between agricultural amendments and river water pollution is, at least in part, circumstantial and tracing techniques are a way to elucidate pathways, dynamics and controls (Granger et al., 2007).

Natural fluorescence may be used to trace dissolved organic matter (DOM) originating from agriculture (e.g. Baker, 2002; Granger et al., 2010; Lapworth et al., 2009; Naden et al., 2010). Recent technological advances in fluorescence spectroscopy mean that it is now possible for fluorescence to be analysed rapidly on small water samples with extreme sensitivity. Its widespread application in characterising DOM in marine, freshwater and wastewater environments has been reviewed by Hudson et al. (2007). Typically, in river water samples, fluorescence peaks are found to coincide with those of tyrosine, tryptophan, fulvic and humic acids. Although in some studies (e.g. McKnight et al., 2001) the chemical structure of those compounds responsible for peaks in fluorescence has been characterised this was not done here and as the provenance of the peaks is therefore unknown the terms tyrosine-like, tryptophan-like, fulvic-like and humic-like are used. Absolute fluorescence values may be related to concentrations of DOM whilst ratios of protein-like to fulvic/humic-like fluorescence may be used to discriminate different sources (e.g. Baker, 2001; Baker, 2002; Baker and Inverarity, 2004; Galapate et al., 1998; Henderson et al., 2009; Lapworth et al., 2009). Furthermore, tryptophan-like fluorescence intensity of a range of water sources has been shown to correlate strongly with Biochemical Oxygen Demand (BOD), phosphate, nitrate, ammonia and dissolved oxygen (Baker and Inverarity, 2004; Hudson et al., 2008). Although Naden et al. (2010) used the Rowden Experimental Research Platform (RERP) in Devon (UK) to demonstrate that natural fluorescence could be used 'within limits' to detect diffuse losses of slurry from 1 ha lysimeters into drainage waters no detailed catchment studies have been undertaken that link diverse agricultural sources of fluorescent DOM with dynamics observed in river water.

The aim of this paper is to develop the use of natural fluorescence to trace DOM derived from livestock farming at the small headwater catchment scale. Here the specific objectives are to: (1) characterise the fluorescence of potential livestock associated pollutants and catchment drainage waters with varying degrees of pollution; (2) collect and analyse high resolution fluorescence data from key source area discharge points in the catchment to evaluate whether it is possible to elucidate transport pathways and their dynamics during hydrological events (including the response following slurry application); and (3) to use fluorescence to attempt to quantify the significance of flow and pollution contributions from an impervious farmyard area.

\section{Study area and methods}

\subsection{Study area}

This research was undertaken in Devon (UK) in the Den Brook catchment (UK grid reference: SX67712 99685). It is a first-order headwater catchment $\sim 0.5 \mathrm{~km}^{2}$ in size (Fig. 1) that is characterised by a slowly permeable, seasonally waterlogged clay soil overlying clay shales of the Crackington formation (Bilotta et al., 2010). According to the Hydrology of Soil Types classification system (Boorman et al., 1995), this soil series (class 24; model J) represents the most common hydrological soil type in England and Wales and is typical of many areas of grassland production (Wilkins, 1982). The catchment receives high levels of rainfall with a 40 -year average annual total of $1050 \mathrm{~mm}$ (Page et al., 2005), the majority of which typically falls in the winter/spring, although in recent years it has been observed that heavy rainfall events during the summer months are increasing (Maran et al., 2008). The catchment is extensively drained to the Den Brook stream by a number of artificial subsurface drains (Fig. 1) consisting of large concrete main pipes that are fed by smaller perforated plastic pipes in a herring bone pattern. Underdrainage is typical in temperate grassland systems as excess water due to poor drainage is a major factor limiting the growth and utilisation of grass (Armstrong and Garwood, 1991; Tyson et al., 1992). Agricultural policies in Britain have resulted in it being one of the most extensively underdrained countries in Europe (Green, 1979). At the peak of this activity approximately 100,000 ha per annum of land was being drained (Robinson and Armstrong, 1987). The low permeability clay soil, steep slopes, small catchment size, and presence of subsurface drains (Fig. 1) mean that the Den Brook has a 'flashy' hydrological response.

The catchment is predominantly intensively managed as mixed grassland sustaining beef and dairy cattle and sheep, and the sward is dominated by perennial ryegrass receiving periodic applications of manure, inorganic fertiliser (N, P and $\mathrm{K}$ ) and excretal returns during the spring/summer. Page et al. (2005) report average stocking densities of 2.5 livestock units per hectare (LSU ha ${ }^{-1}$ ) that vary seasonally with a peak density of $\sim 5.5 \mathrm{LSU} \mathrm{ha}^{-1}$ in late-summer and early-autumn. For the purpose of this paper the catchment can be considered to comprise the following three key elements: (1) farmyard; (2) field sub-catchment; and (3) steep grassland area.

The farmyard is located within the north western part of the catchment (Fig. 1). Within this area there is a silage clamp, manure heap and animal housing (served by a slurry lagoon). The farmyard is thought to be connected to the Den Brook first-order channel by a large drain (farmyard pipe) which intermittently discharges farmyard run-off into the stream. However, the extent of this probably indirect connection is poorly understood. Waste contained within the lagoon is spread within the catchment area when ground conditions allow, typically during the spring/summer.

The field sub-catchment (kale under-sown with grass grazed by sheep/lambs during January 2007 which returned to grassland by 2008) is located in the south western part of the catchment (Fig. 1) and represents $12 \%$ of the catchment area. It slopes at an angle of about $5^{\circ}$ from its SW to NE corner. There is no evidence of artificial drains in this field, and subsurface flow is considered to be negligible due to the low hydraulic conductivity of the subsoil $\left(<10 \mathrm{~mm}^{\text {day }}{ }^{-1}\right)$ (Armstrong and Garwood, 1991).

The steep grassland is located in the central southern part of the catchment (Fig. 1). This part of the catchment drains to the Den Brook by a large subsurface drain (grassland pipe). A road and a woodland area represent its most southerly boundary.

\subsection{Methods}

\subsubsection{Field sampling and measurements}

Spatial and event sampling were undertaken throughout the catchment for fluorescence analysis. On the 11 January 2007, samples were collected from a range of runoff source areas and pathways in the farmyard and wider catchment (Fig. 1). Samples were also collected from key points in the catchment throughout four rainfall events occurring between January 2007 and June 2008. The first event occurred on 17 and 18 January 2007, and discharges were sampled from the field sub-catchment, grassland pipe, farmyard pipe and the catchment outlet. The remaining three events occurred on 29-30 March, 28 May and 2-3 June 2008. During these events, discharges 


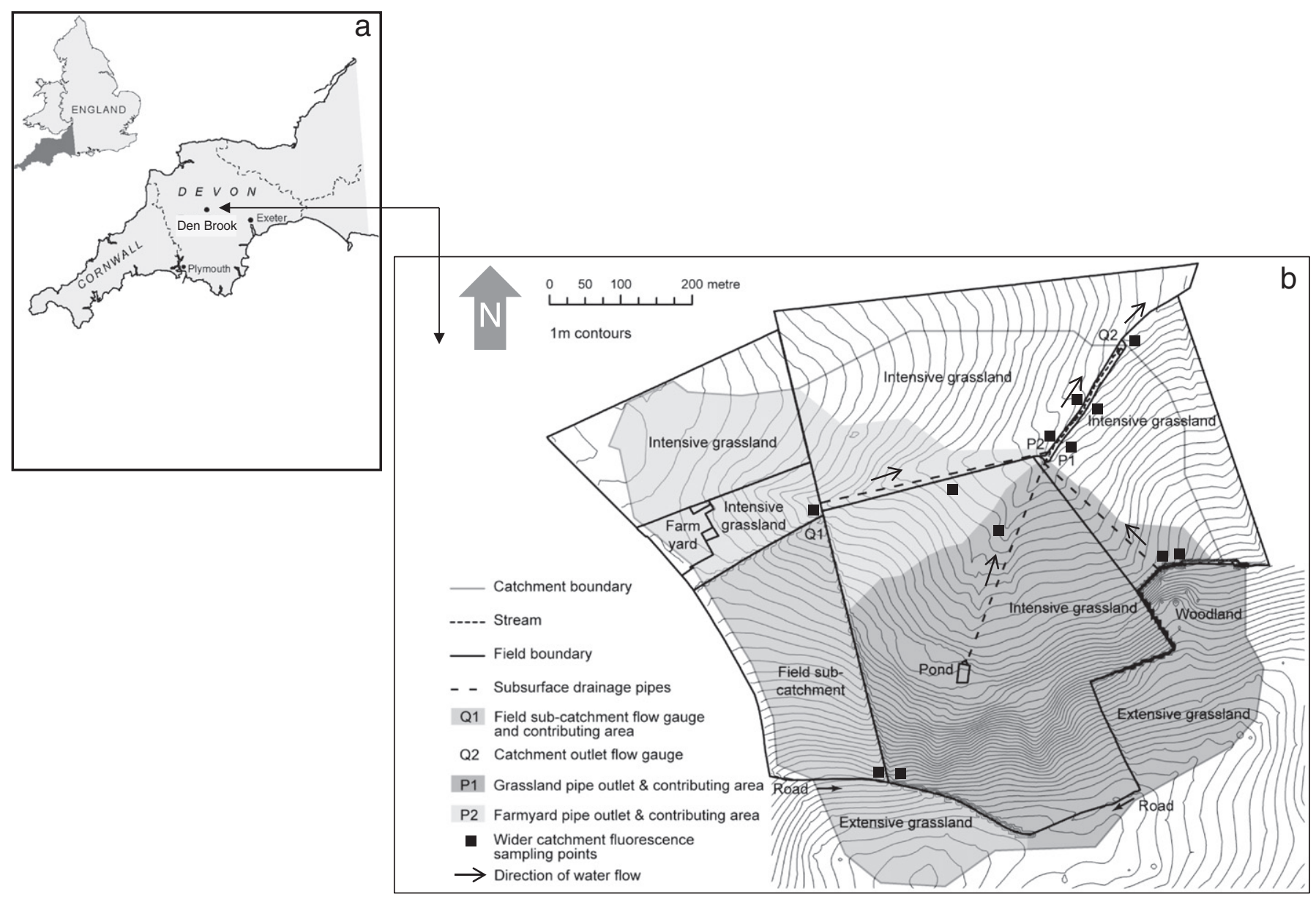

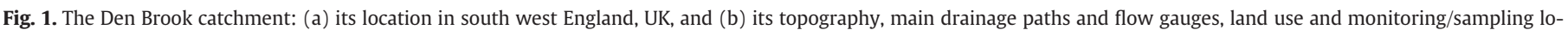

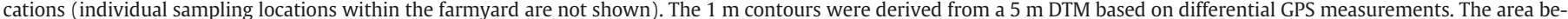

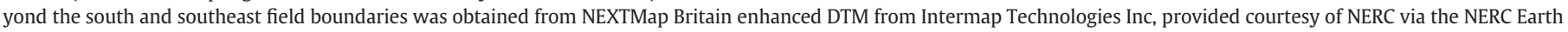
Observation Data Centre (NEODC). Part (b) adapted from Krueger (2009).

were only sampled from the field sub-catchment and catchment outlet.

Manual and automatic samples were collected for the fluorescence analysis. Manual samples were taken directly using acid washed $60 \mathrm{ml}$ amber glass bottles which were filled to the top. During rainfallgenerated events, autosamplers (model: Xian 1000 from Bühler Montec, Manchester) were used to collect $500 \mathrm{ml}$ samples at set time intervals. Subsamples were poured from the plastic Xian bottles into the acid washed $60 \mathrm{ml}$ amber glass bottles after thorough mixing.

Discharge was monitored at the catchment outlet and the field subcatchment. At the catchment outlet it was measured using a standardised trapezoidal flume, as used by the Scottish Environmental Protection Agency (SEPA), installed in 2001. For the field sub-catchment, the nature of the slope and the presence of surrounding banks ensure that all surface run-off is contained and directed towards the NE corner of the field (Fig. 1). In this corner a V notch weir was installed in 2006/ 07. At both sites stage height from which discharge is calculated was measured at 1 minute intervals by pressure transducers located in stilling wells. To convert stage height to discharge, a calibration exercise was carried out which involved manually measuring discharge over the range of stage heights. Uncertainty intervals (minimum and maximum) for discharge at any given stage height were produced by fitting a fuzzy rating curve (Krueger et al., 2009). These uncertainty intervals which estimate the errors associated with the calibration technique (instrument error, operator error, velocity variation in the crosssection) become wider when extrapolating beyond the maximum calibrated stage height at each location.
Precipitation was recorded at the catchment outlet by a tippingbucket rain gauge (Rain-wise Bar Harbor, ME), which recorded the total number of tips per minute (each tip equivalent to $0.254 \mathrm{~mm}$ precipitation).

Measured stream flow event volumes at the catchment outlet were compared to those estimated through hydrological modelling of rainfall and their close agreement gave confidence in the accuracy of the assumed total catchment area (Krueger et al., 2010).

\subsubsection{Laboratory analysis}

All samples for fluorescence analysis were stored in the dark, kept cool (using a freezer box with ice packs and when possible a fridge at $<5{ }^{\circ} \mathrm{C}$ ) and analysed at room temperature within $48 \mathrm{~h}$ of collection. Prior to analysis, samples were filtered using pre-ashed Whatman GFC (1.2 $\mu \mathrm{m})$ glass fibre filters. Fluorescence measurements were carried out on a spectrophotometer (Varian Cary Eclipse) fitted with a Xenon flash lamp using slit widths of $5 \mathrm{~nm}$, an integration time of $12.5 \mathrm{~ms}$ and voltage of $725 \mathrm{~V}$. Excitation wavelengths were varied from 200 to $400 \mathrm{~nm}$ in steps of $5 \mathrm{~nm}$ and emission wavelengths from 280 to $500 \mathrm{~nm}$ in steps of $2 \mathrm{~nm}$. To ensure a high signal:noise ratio only values with an excitation wavelength greater than $240 \mathrm{~nm}$ were considered in the analysis. Absorbance was measured in a $1 \mathrm{~cm}$ cuvette on a UV-vis spectrophotometer (Varian Cary 50) at $1 \mathrm{~nm}$ intervals from 800 to $200 \mathrm{~nm}$.

High values of absorbance at long wavelengths are indicative of inefficient filtering and so samples with values of absorbance at $650 \mathrm{~nm}$ greater than 0.02 were omitted from the analysis. For the 
remaining samples, the absorbance measurements were longwavelength scatter-corrected using the method of Blough et al. (1993). Samples with absorbance at $254 \mathrm{~nm}$ greater than $1.5 \mathrm{AU} \mathrm{cm}^{-1}$ were diluted using Milli-Q water. As in Naden et al. (2010), this threshold was adopted for pragmatic reasons. It is considerably higher than the value of $0.3 \mathrm{AU} \mathrm{cm}{ }^{-1}$ quoted by Ohno (2002) but within the limits found by Holland et al. (1977).

Following manufacturer's instructions, instrument corrections to account for lamp output and for instrument sensitivity were applied to the fluorescence data (Holbrook et al., 2006). Inner-filtering corrections were calculated from the absorbance data using the method of Lakowicz (1983) and applied to the fluorescence data. The fluorescence data were finally converted to Raman units using the method of Lawaetz and Stedmon (2009).

Indices representing tryptophan-like and fulvic/humic-like fluorescence were derived from investigations of known mixtures. Rather than simply taking the fluorescence at, or in the region of the peak of each of the anticipated fluorophores, optimal regions of the excitation-emission matrix (EEM) were identified, which minimised the effect of any overlap in the fluorescence centres and with the Raman line. The wavelengths that define each region are given in Table 1 and the index is an average of the corrected fluorescence intensities in the given region.

Uncertainty was estimated using results of the analysis of 10 consecutive samples from each of the main sampling locations (Table 2). Values are quoted as the measured data plus or minus the ranges presented in Table 2 . The resulting uncertainty captures short term variability in the quality of the water at the sampling point and any variability introduced by sampling, laboratory analysis and data correction. The variability of $\mathrm{TI}$ and TI:FI is greatest in the farmyard pipe discharge. Likely reasons for this are the high TI values of water from the farmyard pipe and the dynamic behaviour of its discharge and TI and FI sources.

\section{Results}

Spatial and event sampling was undertaken for natural fluorescence in the Den Brook catchment to identify the main sources of fluorescent DOM and their responses in drainage waters during storm events and either side of slurry application. The corrected EEMs for a grassland and farmyard water sample are given in Fig. 2a and $b$, respectively. Owing to its concentrated nature with high absorbance the farmyard sample was diluted 500 times prior to analysis. These EEMs show the dominance of the fulvic/humic like signal (FI) in the grassland water sample (peaks in the region $\mathrm{Ex}=220-250$ and $300-380 \mathrm{~nm}$; and $\mathrm{Em}=400-480 \mathrm{~nm}$ ) and the dominance of the tryptophan-like signal (TI) in the farmyard water sample (peaks in the region $E x=280 \mathrm{~nm}$; Em $350 \mathrm{~nm}$ ) (e.g. Baker and Spencer, 2004). The rectangles in Fig. 2 show the areas of the EEM used to calculate TI and FI.

\subsection{Spatial survey}

Fluorescence intensity results from a spatial sampling survey undertaken on 11 January 2007 are shown in Figs. 3 and 4. The fluorescence of a range of animal wastes (e.g. slurry, drainage from a manure heap) and an animal feed (silage) found around the Den Brook farmyard are presented in addition to the fluorescence of drainage waters

Table 1

Definition of fluorescence indices.

\begin{tabular}{lll}
\hline Index & $\begin{array}{l}\text { Excitation wavelength } \\
(\mathrm{nm})\end{array}$ & $\begin{array}{l}\text { Emission wavelength } \\
(\mathrm{nm})\end{array}$ \\
\hline Tryptophan index $(\mathrm{TI})$ & $275-285$ & $346-354$ \\
Fulvic/humic index $(\mathrm{FI})$ & $325-375$ & $450-500$ \\
\hline
\end{tabular}

Table 2

Descriptive statistics of analysis of 10 consecutive samples from four locations in the Den Brook catchment. Samples were taken on 11th January 2007 and fluorescence intensities are reported in Raman Units (RU).

\begin{tabular}{lllll}
\hline Location & Index & Min (RU) & Max (RU) & Range (RU) \\
\hline Field sub-catchment gauge & TI & 0.73 & 0.79 & 0.06 \\
& FI & 2.38 & 2.53 & 0.14 \\
Grassland pipe outlet & TI:FI & 0.30 & 0.32 & 0.01 \\
& TI & 0.52 & 0.54 & 0.02 \\
Farmyard pipe outlet & FI & 1.71 & 1.77 & 0.06 \\
& TI:FI & 0.30 & 0.31 & 0.01 \\
& TI & 3.37 & 3.69 & 0.32 \\
Catchment outlet gauge & FI & 3.12 & 3.29 & 0.17 \\
& TI:FI & 1.07 & 1.14 & 0.08 \\
& TI & 1.97 & 2.08 & 0.11 \\
& FI & 2.48 & 2.56 & 0.08 \\
& TI:FI & 0.79 & 0.83 & 0.04 \\
\hline
\end{tabular}

from the wider catchment. From Fig. 3 it is clear that farmyard drainage waters have a much greater TI and FI (TI 289 to 894 RU and FI 30 to $465 \mathrm{RU}$ ) than those not directly contaminated by farmyard drainage within the wider catchment (TI 0.8 to $1.0 \mathrm{RU}$ and FI 0.4 to $2.5 \mathrm{RU})$. Farmyard drainage waters are also relatively more enriched in TI than FI. This produces higher TI:FI ratios in farmyard drainage waters ( 1.9 to 24.9 ) compared to lower values ( 0.3 to 0.4 ) in drainage waters from the wider catchment (with no direct farmyard input)
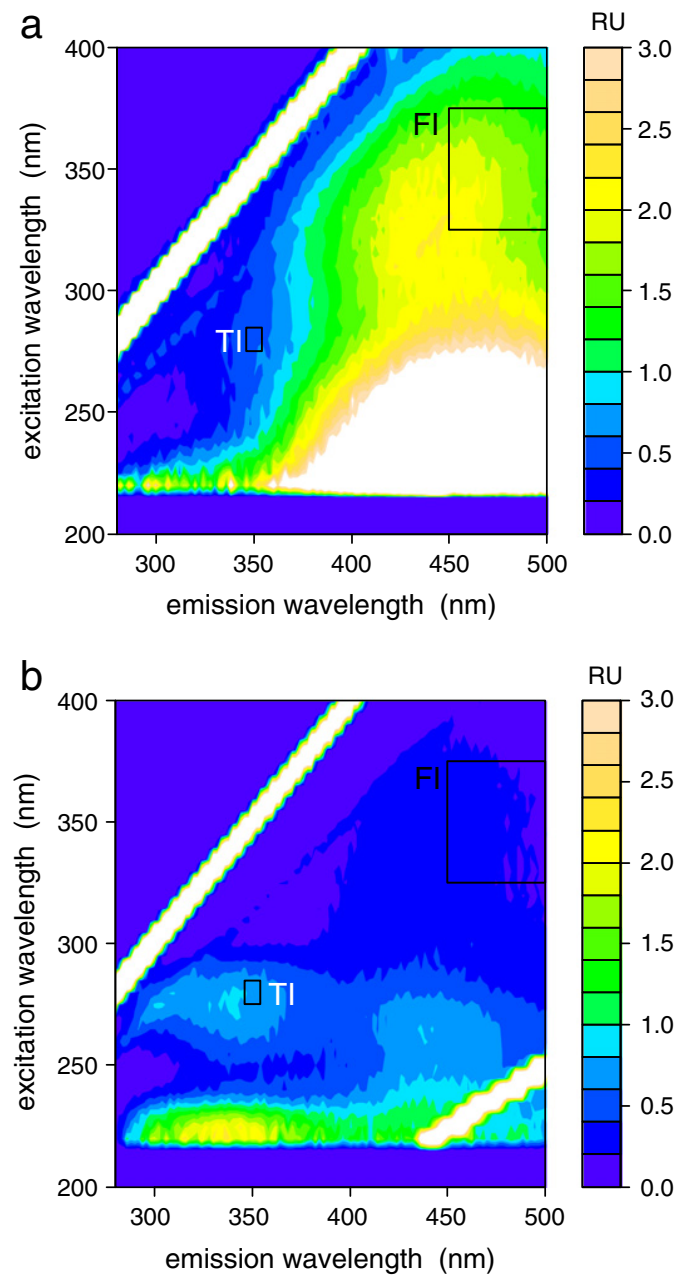

Fig. 2. Example corrected excitation-emission matrices in Raman units: (a) grassland water sample; (b) diluted farmyard water sample (all units given in this EEM reflect dilution $\times 500$ ). Boxes show areas used to calculate the tryptophan (TI) and fulvic/humic (FI) indices as defined in Table 1. 


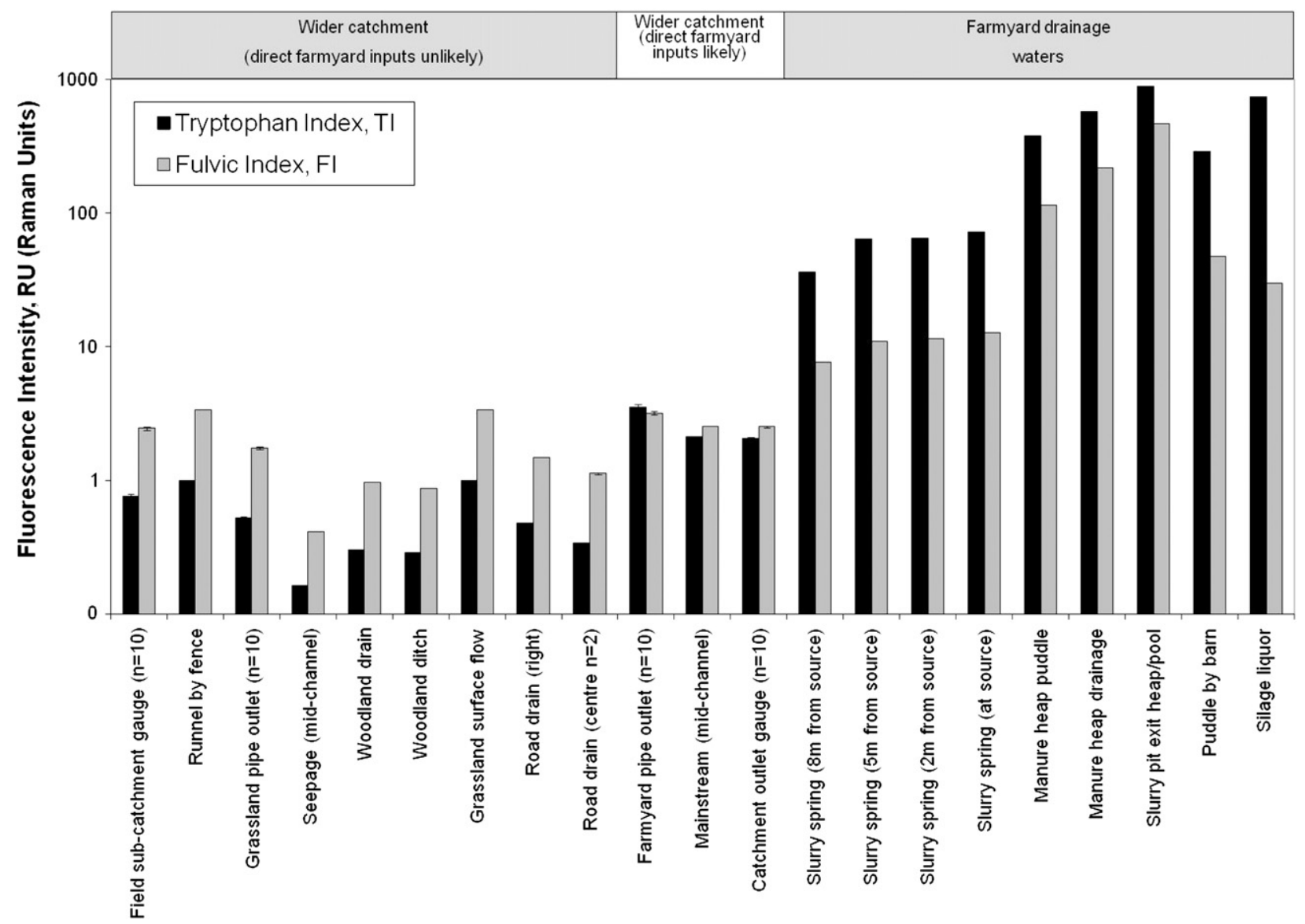

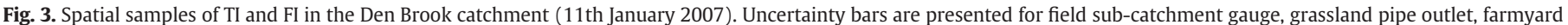
pipe outlet and the catchment outlet gauge (see Table 2).

(Fig. 4). For example, TI:FI ratios in drainage waters from the field sub-catchment and grassland pipe are an eightieth of those of waters draining the silage clamp. Although the TI and TI:FI ratios of the wider catchment drainage waters that are probably contaminated with farmyard sources are intermediate (Figs. 3 and 4), the FI are comparable with other catchment drainage waters. A second spatial survey (not shown) on 18 January 2007 also illustrated the very low TI, FI and TI:FI ratios of the wider catchment drainage waters.

\subsection{Event sampling}

Storm event sampling in 2007 (January) and 2008 (March, May and June) enabled the investigation of the temporal dynamics of the fluorescence signal in waters draining from the field sub-catchment, grassland pipe, farmyard pipe and catchment outlet under winter and summer conditions. Sampling of storms in 2008 also enabled investigation of the dynamics of the fluorescence signal in waters draining from the outlets of the field sub-catchment and the whole catchment during storms pre and post slurry application which took place on 13 and 14th May 2008. Hydrological characteristics of each of the events are presented in Table 3. The total rainfall during each event was at least $15 \mathrm{~mm}$. Rainfall intensity ranged from a minimum of $2.54 \mathrm{~mm} / \mathrm{h}$ in the January 2007 to a maximum of $9.14 \mathrm{~mm} / \mathrm{h}$ in the June 2008 event. Peak discharges were similarly high during the March and May events but significantly lower during the June event.

\subsubsection{Field sub-catchment fluorescence signals}

Water is only discharged from the field sub-catchment when surface runoff is generated by high intensity rainfall events. Therefore, it is very difficult to sample and characterise this fast responding discharge. In all events TI and FI are low at high discharges (e.g. Figs. 5 to 7). Minimum concentrations of TI and FI are roughly coincident with peak discharge in the January 2007 event but precede maximum discharge in the May and June 2008 events. During the May and June 2008 events TI and FI concentrations rise throughout the hydrograph recession, beginning prior to peak discharge. Granger et al. (2010) observed a similar response in DOC from this field throughout the recession limb of the June event. During events, TI:FI ratios either remained constant or were slightly reduced (Figs. 5 to 7). This is a similar pattern to that found in surface/interflow waters draining the RERP lysimeters (P. Naden, pers. comm. 2009).

Data collected during the May and June 2008 storm events followed slurry spreading on the field sub-catchment. TI concentrations do not clearly show enrichment post slurry application. Background TI concentrations are typically 1 RU before and after slurry application and TI:FI ratios are typically 0.3 to 0.4 . Similar observations at the RERP lysimeters showed no significant TI:FI response in surface/ interflow drainage following slurry spreading (Naden et al., 2010). At Rowden, TI:FI ratios of surface/interflow water were typically 0.4-0.6 RU whilst TI values typically ranged from 0.5 to $1.5 \mathrm{RU}$ (Naden et al., 2010; P. Naden, pers. comm. 2009).

\subsubsection{Grassland fluorescence signals}

During the January 2007 event and in contrast to drainage from the field sub-catchment the TI and FI concentrations are positively related to flow in discharge from the grassland pipe (Fig. 5). The TI increases from 0.6 RU to 0.8 RU whilst the FI increases from 1.9 RU to $2.9 \mathrm{RU}$; with maximum values occurring prior to the flow peak in 


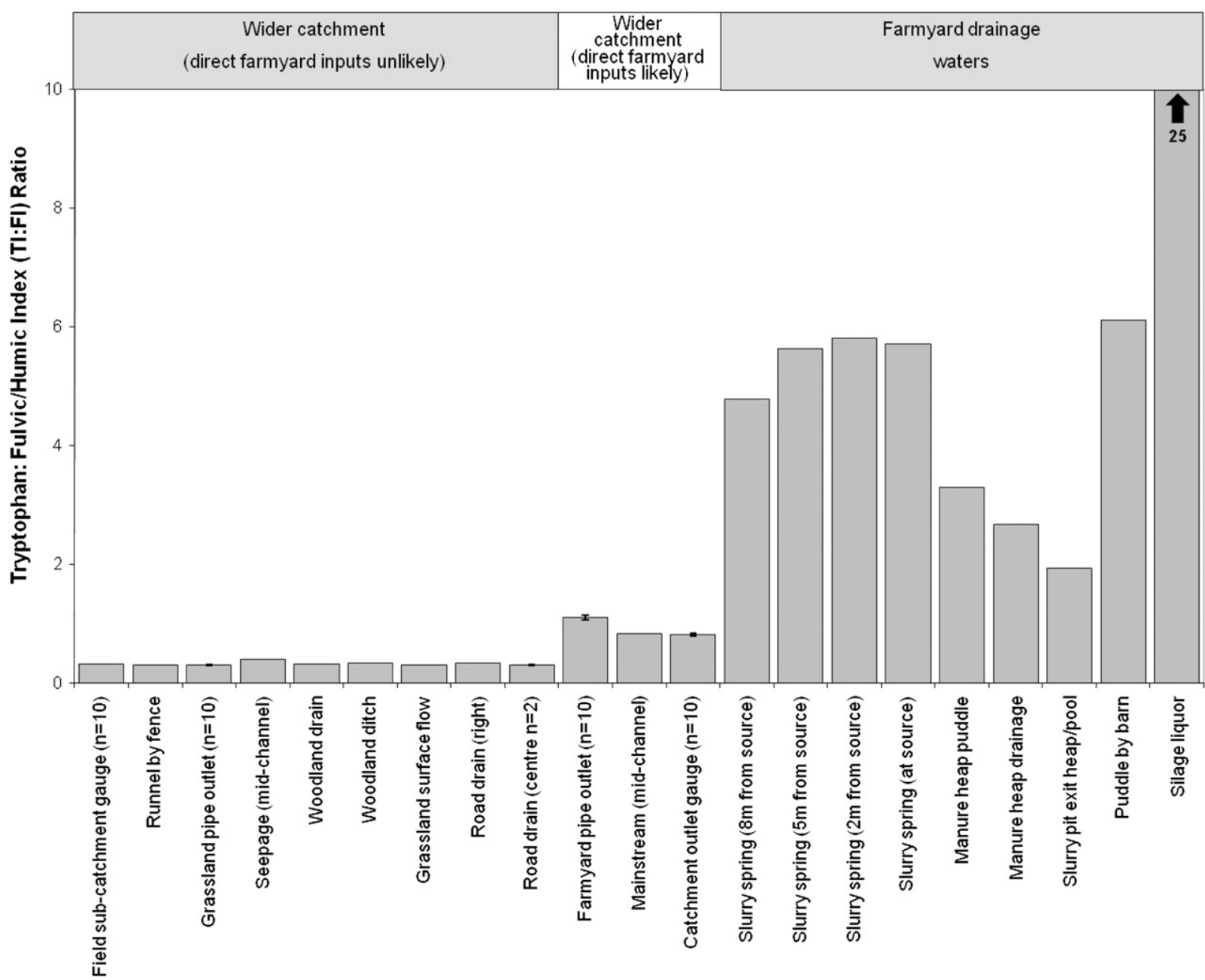

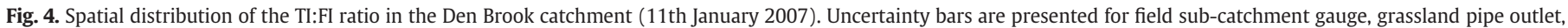
farmyard pipe outlet and the catchment outlet gauge (see Table 2).

Table 3

Hydrological characteristics of the flow events monitored in the Den Brook catchment during January 2007 and March, May and June 2008.

\begin{tabular}{lllll}
\hline \multirow{2}{*}{$\begin{array}{l}\text { Hydrological } \\
\text { characteristics }\end{array}$} & \multicolumn{3}{l}{ Rainfall events monitored } \\
\cline { 2 - 5 } & $\begin{array}{l}17-18 \text { January } \\
2007\end{array}$ & $\begin{array}{l}29-30 \text { March } \\
2008\end{array}$ & $\begin{array}{l}\text { 28 May } \\
2008\end{array}$ & $\begin{array}{l}\text { 2-3 June } \\
2008\end{array}$ \\
\hline $\begin{array}{c}\text { Total event rainfall (mm) } \\
\text { Maximum event rainfall } \\
\text { intensity (mm h }\end{array}$ & 15 & 17 & 24 & 15 \\
$\begin{array}{c}\text { Peak discharge at catchment } \\
\text { outlet }\left(\mathrm{m}^{3} \mathrm{~s}^{-1}\right)\end{array}$ & 0.54 & 3.81 & 4.57 & 9.14 \\
\hline
\end{tabular}

both cases. The proportional increases in TI and FI mean that a constant low TI:FI ratio ( 0.3) prevails throughout the event (Fig. 5).

\subsubsection{Farmyard pipe fluorescence signals}

At the start of the January 2007 event TI, FI and TI:FI ratios were high in the discharge from the farmyard pipe (Fig. 5). TI had a maximum concentration of $6.5 \mathrm{RU}$ which is considerably higher than that found in drainage from the field sub-catchment (maximum 1.0 RU) and grassland (maximum $0.8 \mathrm{RU}$ ) during this event (Fig. 5). As flow in the farmyard pipe increased, both TI and FI decreased rapidly. The reduction in $\mathrm{TI}$ ( 6.5 to $1.8 \mathrm{RU}$ ) was greater than in FI (3.9 to $2.8 \mathrm{RU}$ ) resulting in a marked decrease in the TI:FI ratio (from 1.7 to 0.6) (Fig. 5).

\subsubsection{Catchment outlet fluorescence signals}

TI, FI and TI:FI ratio responses at the catchment outlet gauge reflect the mixing of upstream drainage waters which include widespread surface runoff (including the field sub-catchment) and contributions from the grassland and farmyard pipes.

During the May and June 2008 events (Figs. 6 and 7) there is an initial sharp rise in the values of the TI, FI and the TI:FI ratio from pre-event values of $0.5-1$; peaks are most pronounced during the June 2008 event. During the May and June events the TI rose to values of 4 and 30, respectively. During the same events the FI rose to values of $2.8 \mathrm{RU}$ and $13 \mathrm{RU}$, respectively. In both events the greater response in the $\mathrm{TI}$ index produced peaks in the TI:FI ratio of 1.6 and 2.3, respectively.

In the January 2007 (Fig. 5) and March 2008 events the start of sampling followed the onset of the events so it was not possible to characterise pre-event conditions and thus confirm the existence of initial peaks. However, the TI and FI show initial high levels that subsequently recede. In January and March the TI has initial values of 3.6 RU and 2.1 RU respectively, whilst the FI has values of 3.1 RU and $1.5 \mathrm{RU}$, respectively.

In all four events the $\mathrm{TI}$ recession is stronger than the FI recession. The resulting TI:FI ratio, therefore, recedes steeply throughout the events from relatively high early values of 1.2 in January 2007, 1.4 in March 2008, 1.6 in May 2008, and 2.3 in June 2008. Furthermore, data from May and June 2008 illustrate that FI values, and to a lesser extent TI values, from event recession limbs remain elevated at $\sim 2.5 \mathrm{RU}$ and $\sim 3.0 \mathrm{RU}$ respectively, relative to their pre-event levels 

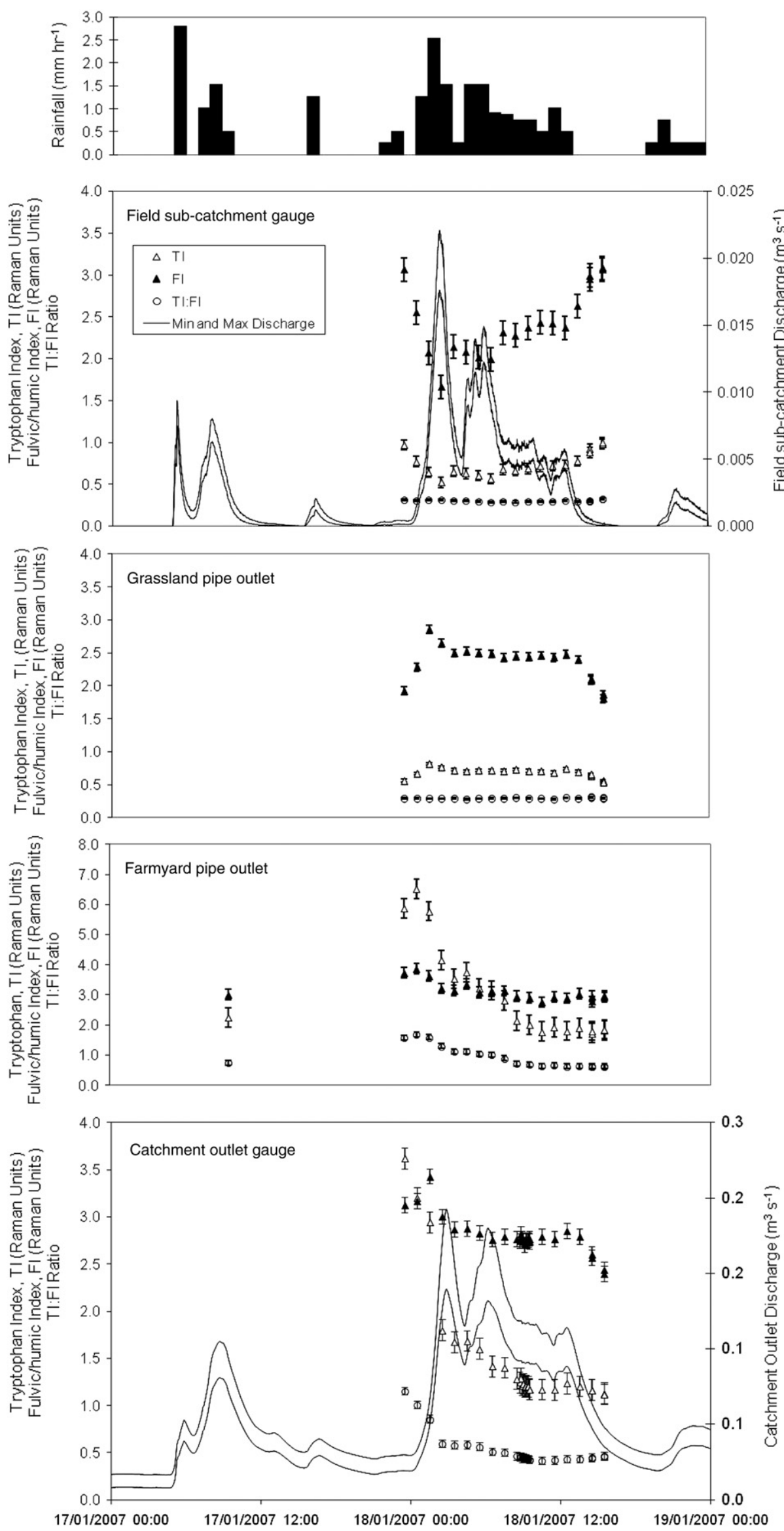

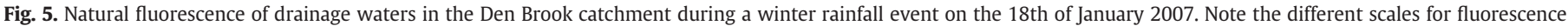
indices from the farmyard pipe outlet. 

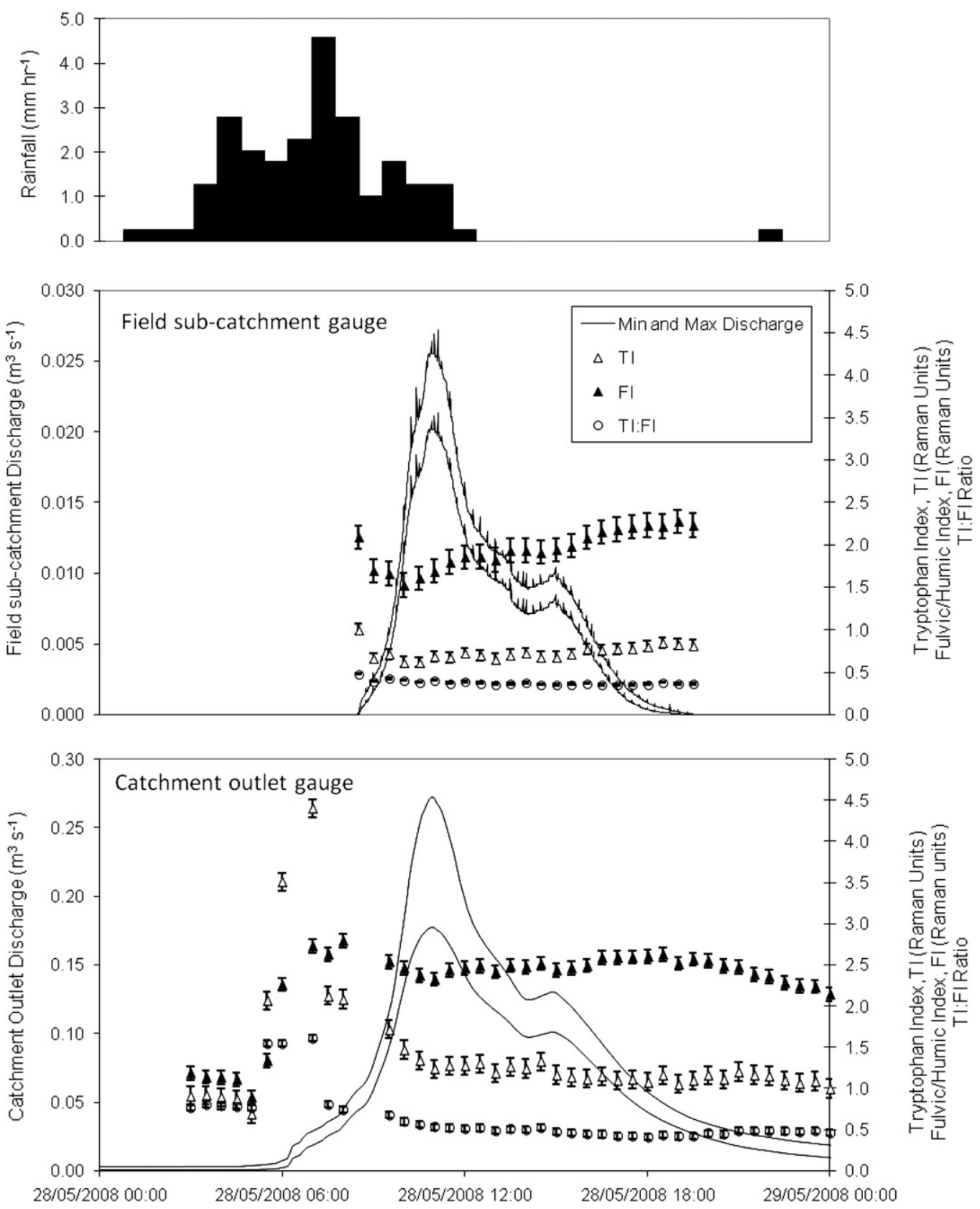

Fig. 6. Natural fluorescence of drainage waters in the Den Brook catchment during a summer rainfall event on the 28 th of May 2008.

(Figs. 6 and 7). This produces higher TI:FI ratios in pre-event samples relative to those from the event recession.

\subsection{Significance of flow and pollutant contribution from the farmyard pipe}

\subsubsection{Quantifying flow components}

The strongly contrasting TI signals of coincident discharges from the wider Den Brook catchment (grassland pipe and field subcatchment) and the farmyard pipe enable the use of a 2 component mixing model (Eq. (1)) to separate discharge contributions at the catchment outlet (Fig. 8). Discharge from the farmyard pipe can be estimated using Eq. (2). The TI signal from the farmyard pipe represents drainage from a range of sources with contrasting TI concentrations (Fig. 3).

$Q w=Q o\left(\frac{C o-C f}{C g-C f}\right)$
$Q f=Q 0-Q w$

where, $Q w$ is flow from wider catchment, $Q o$ is flow at the catchment outlet, $\mathrm{Qf}$ is flow from the farmyard pipe, $\mathrm{Cg}$ is TI from the grassland pipe, $C f$ is $\mathrm{TI}$ from the farmyard pipe, and $C o$ is TI at the catchment outlet.

The application of this model assumes that the TI of the wider catchment drainage water is adequately represented by the grassland pipe and that conservative mixing occurs prior to sampling at the catchment outlet with no additional in-channel sources. This is a reasonable assumption given that the grassland pipe is unlikely to be directly contaminated by farmyard sources of TI and travel times from where the pipe discharges mix to the catchment outlet (distance of $<200 \mathrm{~m}$ ) are likely to be very short ( $<5 \mathrm{~min}$ ) under most flow conditions. Likely minimum and maximum flow proportions (Fig. 8) were estimated by using all combinations of the minimum and maximum TI for each of the three locations (see ranges applied to data in Table 2). 

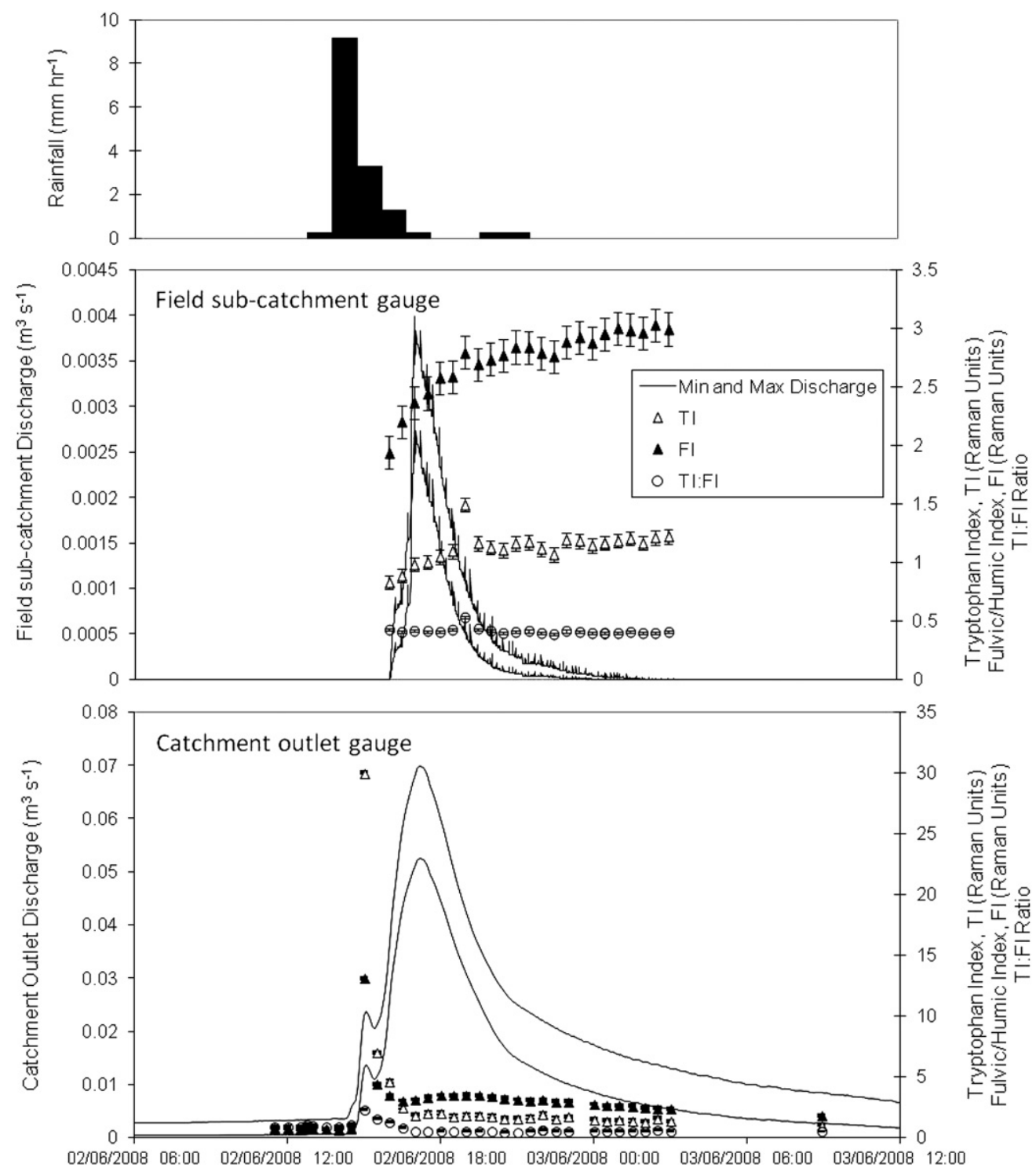

Fig. 7. Natural fluorescence of drainage waters in the Den Brook catchment during a summer rainfall event on the 2nd of June 2008 .

Uncertainty in the magnitude of the flow components (Fig. 8) increases throughout the event as the $\mathrm{TI}$ from each location converges. From the flow separation illustrated in Fig. 8, it is clear that at the start of the event the farmyard pipe contributes at least half of the flow $(>52 \%)$. This results in the very high TI concentration at the outlet at this time. However, the wider catchment responds quickly to the rainfall due to the already wet ground and within $3 \mathrm{~h}$, at the first hydrograph peak, it represents $62-75 \%$ of the outlet flow. The rapidly increasing contribution from the wider catchment prevents the farmyard pipe producing a clear peak in TI at the outlet. During a summer flow event we would expect a slower response from wider catchment due to the need for it to wet up and a clear initial peak in pollutants from the rapid contribution of the farmyard pipe due to the impermeable surface and effective drainage path (e.g. June 2008 event in Fig. 7).

\subsubsection{Quantifying flux components}

Fluxes of tryptophan-like material, as indicated by TI, from the wider catchment and farmyard can be estimated using the discharges derived from the two component mixing model (Fig. 9) and measured concentrations in each of the discharges (Fig. 8). At the start of the January 2007 event, the farmyard contributes $92-95 \%$ of the TI flux at the outlet (Fig. 9) although its discharge contribution may be as low as $52 \%$ (max of $64 \%$ ). As the wider catchment responds, the proportion of the outlet tryptophan-like flux contributed by the farmyard decreases (Fig. 9). Although the farmyard pipe may only account for $26 \%$ ( $\max$ of $55 \%$ ) of the total flow at the outlet during this event it accounts for a minimum of $61 \%$ ( $\max$ of $81 \%$ ) of the total tryptophan-like flux.

3.3.3. Using tryptophan concentrations to estimate the amount of slurry

An indication of the amount of slurry being transported from the farmyard may be estimated by relating the measured tryptophan index (TI) of a given slurry to that in the discharge from the farmyard pipe. It is necessary to assume that all tryptophan-like material is derived from slurry and that the source has a signal similar to the given slurry. As other sources of tryptophan-like material are likely to be important (see Fig. 3), the estimated amount of slurry discharged from the farmyard pipe is likely to be a maximum value. Regression analysis was undertaken on the TI of the dilution series of a slurry used in the Rowden 2007 experiment (Naden et al., 2010). The TIs of six dilutions of the slurry, ranging from 1 to $5 \mathrm{~g}$ slurry/L deionised water, were determined. A strong linear relationship resulted with an $r^{2}$ value of 0.997 (Eq. (3)).

$\mathrm{TI}=0.8136 C-0.1553$ 

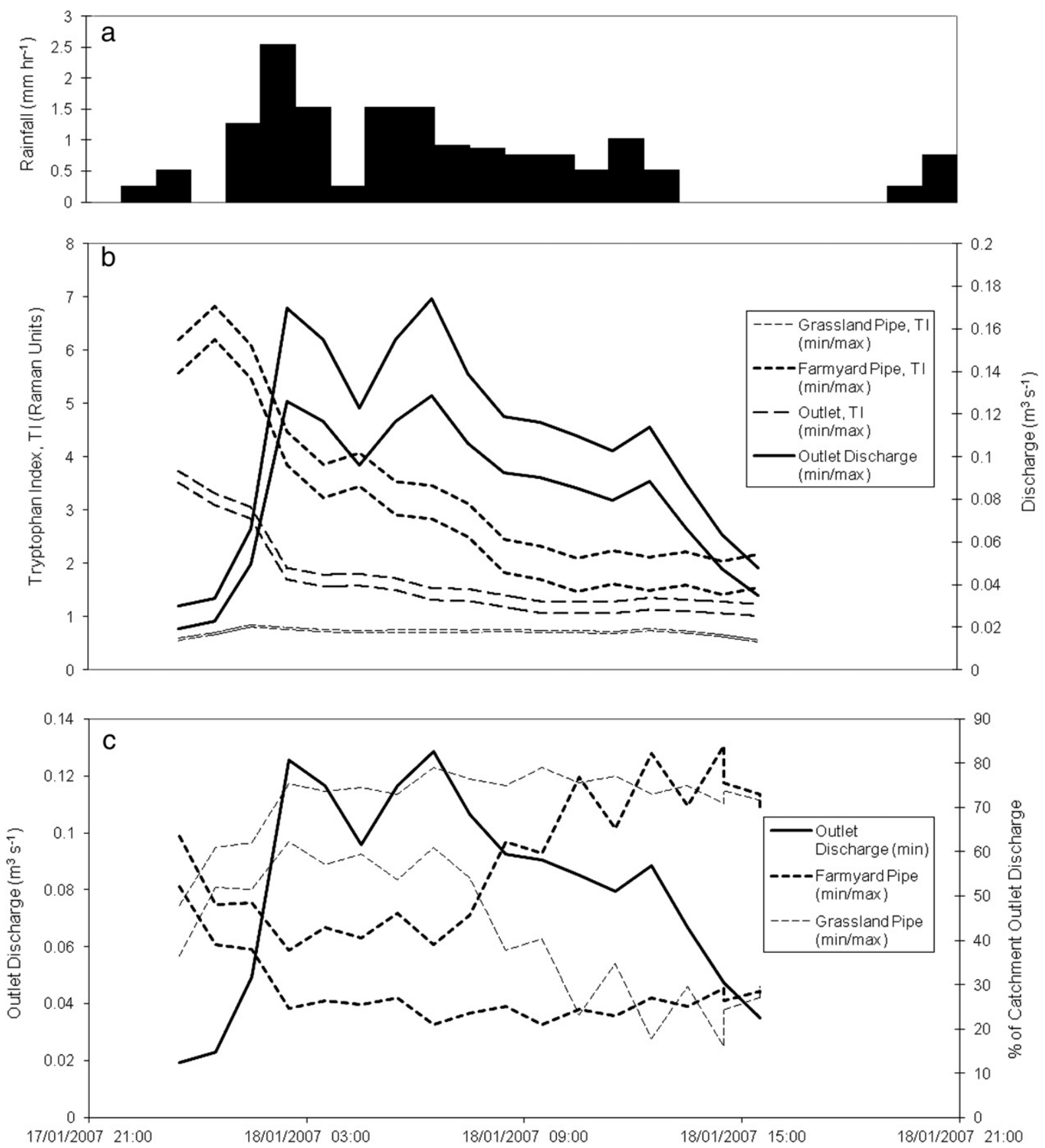

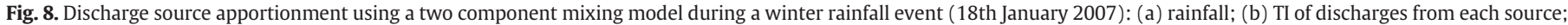
and (c) calculated flow components. Note: uncertainty is illustrated with minimum and maximum TI values (see Table 2) and resulting flow components.

where, TI is Tryptophan Index (RU) and $C$ is the concentration of slurry (g slurry/L water).Using this relationship, the total (maximum) amount of slurry discharged from the farmyard pipe during the $16 \mathrm{~h}$ January 2007 storm event was estimated between 5.4 and 11.1 tonnes. The maximum instantaneous flux was estimated as $0.19-0.35 \mathrm{~kg} / \mathrm{s}$.

\section{Discussion}

\subsection{Characterising the fluorescence of potential livestock farming} associated pollutants and catchment drainage waters

Withers et al. (2009) state that there is very little comparative information on the significance of the multiple sources of pollutants (in their case P) entering headwaters. Here, both spatial surveys in
January 2007 successfully characterised the natural fluorescence of DOM in drainage waters throughout the Den Brook headwater catchment. The distinct TI:FI ratios of farmyard drainage waters (contaminated with animal feeds and wastes) when compared to drainage waters from the wider catchment (Fig. 4) confirm the potential capabilities of natural fluorescence as a low-cost and rapid technique for tracing farmyard pollutants as proposed by Baker (2002). The high farmyard ratios are likely to reflect the presence of proteins containing tryptophan amino acids. Ohno and Bro (2006) also report distinct relatively high TI:FI ratios in water extracts from manure as opposed to soil.

Variations in the dominance of particular phases of pollutants between the various sources are also likely to explain, in part, observed concentration differences. For example, Withers et al. (2009) report greater proportions of soluble $P$ in runoff from farmyards as opposed 

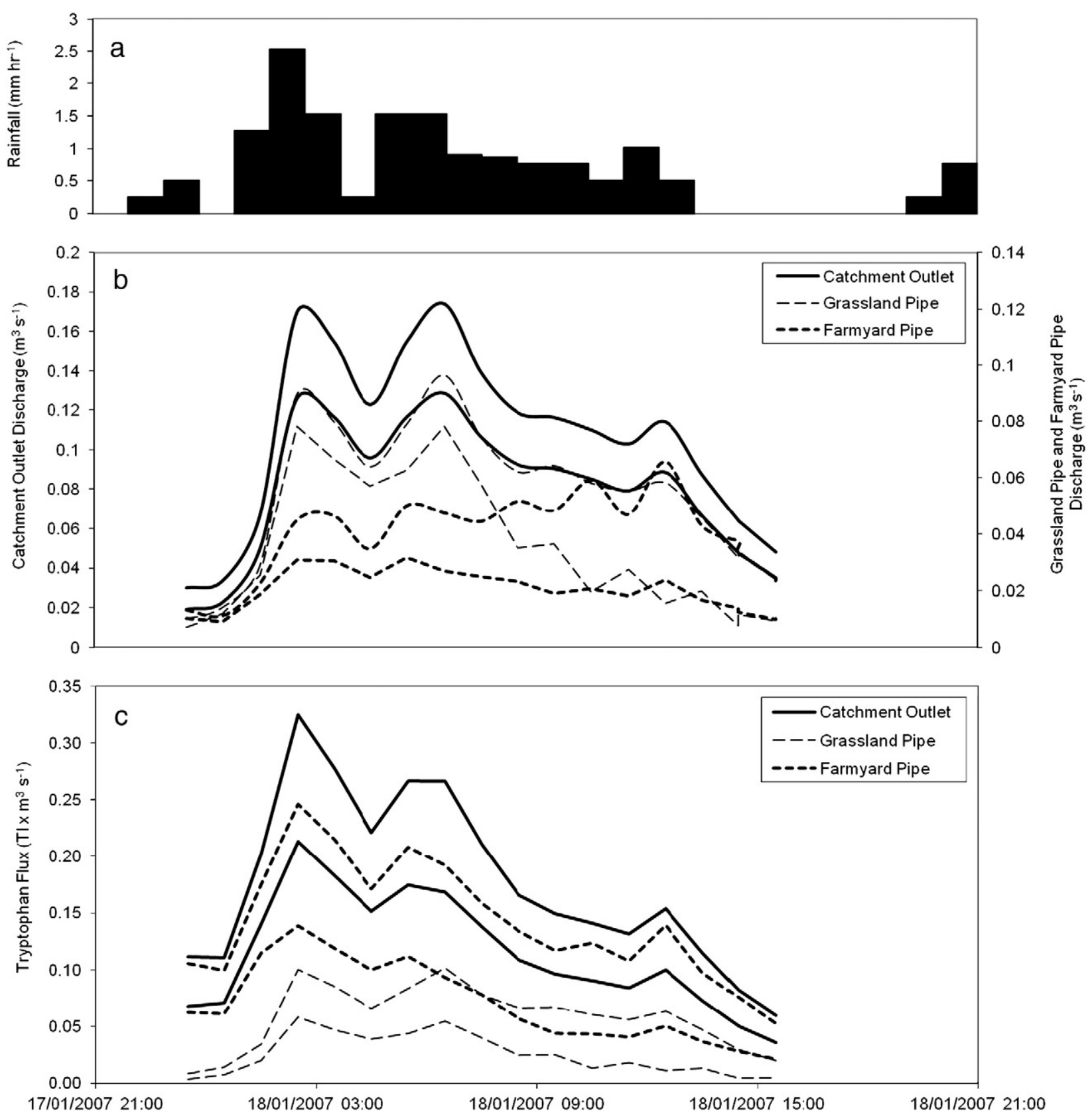

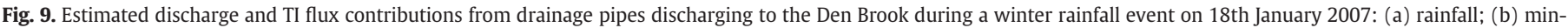

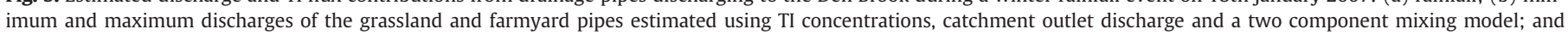
(c) minimum and maximum TI fluxes in the discharges from the grassland pipe, farmyard pipe and catchment outlet that are presented in (b).

to agricultural fields. Furthermore, Ohno and Bro (2006) state that even when soils had been amended with manure TI:FI ratios remained very low suggesting that tryptophan may become strongly sorbed onto soil particles. Soluble phase pollutants (e.g. dissolved P and organic carbon) are important as they are readily transported through river systems and may play a crucial role in regulating biotic processes such as algal and bacterial productivity which then impact on dissolved oxygen concentrations, food web structure, and microbially controlled biogeochemical transformations (Wetzel, 2001; Sobczak and Findlay, 2002).

Acknowledging the different processing methods applied to fluorescence data, the TI:FI ratios observed in the Den Brook catchment are comparable to those reported by Baker (2002) from farms in NE England. The particularly strong TI:FI signal observed in Den Brook silage liquor of 25 is consistent with the values of $>20$ reported for silage liquors from Cockle Park Farm, Morpeth, NE England. Furthermore, the
TI:FI signals observed from Den Brook farmyard sources (excluding silage liquor) of $\sim 2-6$ closely match those reported for cattle and pig slurries for two NE England farms of $\sim 2-5$. TI:FI signals in samples from the wider Den Brook catchment (unlikely to be directly contaminated with farmyard sources) of 0.3-0.4 closely match values reported for rivers throughout the British Isles (October 1998-August 2000; $\mathrm{n}=242$ ) of $0.37+/-0.41$ (Baker, 2002).

Thus natural fluorescence could be used to rapidly detect the presence of pollution from animal wastes and/or feeds in headwater streams. The TI:FI ratios may be interpreted to distinguish the likely sources of the pollution. However, we must acknowledge the likely high temporal variability in pollutant concentrations in drainage waters from many of the above mentioned sources. This is comparable to observed large temporal variations in P concentrations in runoff from farmyards, roads and fields (Withers et al., 2009). Furthermore, as human waste also fluoresces in the same regions as pollution from 
animal wastes/feeds (e.g. Hudson et al., 2008) distinguishing this signal in catchments with sewage effluent inputs or septic tank discharges may be problematic.

\subsection{Elucidating the transport pathways and dynamics of livestock} farming associated pollutants during hydrological events

\subsubsection{Fluorescence of drainage waters: the Den Brook grassland and field} sub-catchment

TI, FI and TI:FI ratios in discharges from the grassland pipe and field sub-catchment are low relative to those at the catchment outlet gauge (Figs. 5 to 7). Flow in the grassland pipe represents both surface and throughflow water from a large grassland area. Fluorescent signals may be produced by animal excreta, microbial activity and leachates from soil and vegetation (e.g. Ohno and Bro, 2006). Observed rising concentrations of TI and FI with increasing discharge during the January 2007 event (Fig. 5) may be explained by the mobilisation of DOM-rich water from within the pipe and from grassland soils. However, the TI:FI ratio of drainage water stayed relatively constant at 0.3 ; consistent with DOM contributions from similar source materials throughout the event.

Flow from the field sub-catchment is dominated by surface runoff. Fluorescent signals may originate from a range of grassland sources as described above. In contrast to the fluorescence response of drainage from the grassland pipe (observed during the January 2007 event), discharge from the field sub-catchment showed a rise in TI and FI throughout hydrograph recessions of the May and June 2008 events (Figs. 6 and 7). Coincident monitoring of the June event by Granger et al. (2010) showed that the increasing fluorescence through the recession of the event was consistent with rising DOC. This fluorescence response may reflect the later arrival of waters following longer pathways from more distant parts of the field which will thus have greater opportunities to accumulate DOM as indicated by DOC, tryptophanlike and fulvic/humic-like materials.

\subsubsection{Fluorescence of drainage waters: the Den Brook catchment outlet}

Although impervious surfaces, with rapid hydrological response, are typically found within urban areas (e.g. Old et al., 2003), farmyards may be significant in rural headwater catchments (Withers and Jarvie, 2008). Several researchers have found runoff from these surfaces to be polluted with nutrients (e.g. Edwards et al., 2008; Edwards and Hooda, 2008) of which large proportions are dissolved and hence readily transported and bio-available (Withers et al., 2009). Here, the early sharp peaks in TI, FI and the TI:FI ratio during the May and June 2008 events are consistent with the rapid arrival of drainage with a high pollutant load from the farmyard pipe (Figs. 6 and 7). Furthermore, Granger et al. (2010) stated that the high ammonium concentrations at the catchment outlet gauge, early in the June 2008 event, were indicative of a farmyard runoff contribution. With the onset of rain the impervious farmyard surfaces, contaminated with animal waste and feed, are likely to immediately generate runoff that is quickly routed through the farmyard pipe. This was also observed during the January 2007 event when the farmyard pipe responded with initial high values of TI, FI and the TI:FI ratio (1.6) which rapidly decreased (FI to a lesser extent) with increasing flow (Fig. 5). This is consistent with TI being mobilised from the farmyard and subsequently being diluted by runoff containing appreciable fulvic/humic-like material but less tryptophan-like material from the surrounding fields.

As farmyard runoff may be generated at any time of year in response to even small amounts of rainfall, pollutant inputs may occur during the most ecologically sensitive periods of spring and summer in contrast to diffuse inputs from agricultural fields (Withers et al., 2009). In the Den Brook catchment, initial peaks in fluorescence and flow at the catchment outlet were most pronounced during the June 2008 storm event when the wider catchment was slow to respond to rainfall (Fig. 7;
Table 3). Although a similar total amount of rain fell as in the January event and its intensity was $>3$ times greater, peak flows were only a third of those recorded in January (Table 3). Under these low flow conditions, whilst the soils in the wider catchment remained unsaturated, water was quickly routed from the farmyard and discharged into the Den Brook. The lower levels of the TI:FI ratio $(\sim 0.5)$ on the falling limb of the hydrograph, compared to the immediate pre-storm values ( 1.0), are likely to reflect relatively large contributions of water (possibly subsurface) from the grassland pipe and the field sub-catchment with low TI:FI ratios and a reduced ratio in discharge from the farmyard pipe (Fig. 7). The low TI:FI ratios of water draining the field subcatchment were witnessed during the recession limbs of events in May and June 2008 when values ranged from 0.35 to 0.45 .

During winter events (e.g. January 2007) when soils are more saturated the catchment is more responsive to rainfall and discharge from the farmyard pipe is more likely to coincide with higher flows from the field sub-catchment and grassland pipe and therefore experience greater dilution in the Den Brook (see Fig. 9).

The impact of such events on water quality at the catchment outlet will strongly depend on the pollutant concentrations in runoff from the farmyard; the likely high temporal variability of which was discussed earlier.

\subsubsection{Fluorescence of drainage waters from the field sub-catchment: response following slurry application}

Elevated nutrient concentrations have been reported in runoff/ drainflow from agricultural land following the application of manure/ fertiliser (e.g. Naden et al., 2010; Withers et al., 2003; Withers and Bailey, 2003). Here water samples from the field sub-catchment gauge during events occurring 2 and 3 weeks after slurry application did not show enhanced TI concentrations or TI:FI ratios (loss to the subsurface is likely to be minimal owing to the clay soil) (Figs. 5 to 7). This is consistent with previous research that has reported high concentrations of slurry constituents in surface runoff immediately after slurry application that rapidly decreased with time (Edwards and Daniel, 1993; Smith et al., 2001; Westerman and Overcash, 1980; Withers and Bailey, 2003). It is likely that the absence of underdrainage in the field sub-catchment is the primary reason for a lack of response in the drainage waters. Strong adsorption of the slurry onto soil particles and microbial break-up and immobilisation of fluorescent DOM are two possible explanations for the lack of response in surface runoff.

Fluorescence degradation experiments undertaken at the RERP and reported in Naden et al. (2010) provide support for these processes. In these experiments slurry was applied to pots of the sterile medium 'vermiculite' and at weekly intervals the fluorescence signal was determined through extraction using DI water. Results demonstrated a large initial loss of fluorescence due to adsorption of the slurry onto the medium. Adsorption onto a grassland/soil surface is unknown. The strong TI signal present after 1 week rapidly declines by a factor of four in just 4 weeks. Naden et al. (2010) assumed this loss was due to microbial activity breaking down the molecules associated with the protein-like fluorescence. Furthermore, Ohno and Bro (2006) compared the fluorescence of aqueous extracts from manureamended versus unamended soils to discover that fluorescence signatures were very similar (i.e. low tryptophan). The proposed interpretation here was also that fluorescent species may be sorbed onto soil surfaces or microbially immobilised. However, microbial activity within soils may also contribute fluorescent molecules. There is clearly a need to better understand the impact of soil microbial processes with respect to the fluorescence of drainage waters.

\subsection{Significance of flow and pollution contributions from an impervious farmyard area}

Withers and Jarvie (2008) emphasised the need for further data on fluxes of pollutants (in their case P) associated with runoff from 
farmyard areas to more fully understand their relative importance and contribution to downstream loads. In the current study the application of a two component mixing model allowed an assessment of the timing and relative importance of the TI flux and discharge contribution from the farmyard to the catchment outlet. The farmyard pipe was shown to respond quickly at the start of the event with a significant contribution to the instantaneous outlet discharge (more than half: Fig. 8) and an extreme contribution to the instantaneous outlet TI flux (almost all: Fig. 9). Furthermore, the farmyard pipe contributes a significant amount of the event total outlet discharge (26-55\%) and may account for a major proportion of the event total outlet TI flux (61-81\%). This illustrates how important and dynamic the impact of an 'intermediate source' of pollution may be on a headwater stream. Other intermediate sources e.g. septic tanks have also been demonstrated to be important inputs of nutrients to rural headwater streams (Jarvie et al., 2010).

The equivalent maximum amount of slurry discharged by the farmyard pipe was estimated, using a regression equation derived from the TI of a dilution series of slurry samples, to be between 5.4 and 11.1 tonnes. Where drainage waters from farmyards are not contaminated by other sources of TI (in this case silage liquor was a likely contributor) a more accurate estimate of the flux of slurry could be derived. Furthermore, there is potential to relate the TI of the farmyard pipe discharge to other nutrient concentrations, BOD and dissolved oxygen concentrations (cf. Baker and Inverarity, 2004) although the variability in such relationships would need to be explored.

\section{Conclusions}

This novel study has successfully applied the natural fluorescence technique to trace key pollutants from livestock farming through a typical underdrained small but steep headwater catchment with seasonally waterlogged clay soils. Only immediate pollutant losses are measured here as other fractions may be absorbed onto soil particles and be mobilised later. Strong fluorescence signals (TI and TI:FI ratio) associated with waters draining the farmyard contrasted to low level signals in unpolluted surface waters, confirming its potential as a tracer of dissolved and thus bio-available and readily transported livestock farming derived pollutants.

Changes in fluorescence intensities of drainage waters throughout storm events allowed an assessment of the dynamics of key pollutant sources. The farmyard area of the catchment studied was shown to contribute polluted runoff in any season very early in storm events in response to small amounts of rain when flows in the Den Brook first-order channel are likely to be low. Effective tracing of farmyard pollutants using fluorescence was confirmed by the coincident peak of ammonia during the June event. It is of widespread significance that large pollutant contributions from impervious farmyards may enter headwater streams during the most ecologically sensitive periods of spring and summer. The application of slurry to the field sub-catchment did not elevate the fluorescence of drainage waters during storm events occurring 2 and 3 weeks later. Thus when slurry is applied to undrained fields the fluorescent DOM may become quickly adsorbed onto soil particles and/or immobilised through bacterial breakdown.

Fluorescence intensities of drainage waters were successfully combined with discharge data to estimate pollutant fluxes from key sources. The application of a mixing model to quantify the ungauged flow components, in this case the farmyard and wider catchment, was demonstrated and the method may be applicable elsewhere. The farmyard was shown to be the dominant source of fluorescent DOM during storm events in the catchment. This reinforces the case made by Withers et al. (2009) of the importance of considering intermediate (e.g. farmyard runoff) and not only traditional point (i.e. sewage treatment discharges) and diffuse (i.e. agricultural field runoff) pollutant sources. The potential to calibrate fluorescence intensity to actual pollutant concentration/flux (in this case slurry) was demonstrated for the farmyard runoff although the uncertainty that is likely to be produced by diverse and dynamic sources of fluorescence needs further investigation. In a well constrained system it could increase the efficiency and effectiveness of monitoring.

Quantifying fluxes of key pollutants is critical to effectively managing headwater stream pollution. Source apportionment studies should be integrated with flux estimation to enable detailed assessments of the degree of abiotic and biotic nutrient assimilation. The most effective reductions in pollutants may be achieved through reducing major sources and enhancing instream assimilation (e.g. Withers and Jarvie, 2008). Increasing pressures on rivers from climate change, intensification of agriculture, water abstraction, and urban expansion will increasingly require effective management of pollutants.

Therefore, high spatial and temporal resolution measurements of fluorescence, possibly using novel in-situ fluorimeters, may have great potential in quickly identifying and quantifying the presence, dynamics and sources of pollutants in catchments from livestock farming. This is likely to support the sustainable management of agricultural activities by highlighting problem areas, targeting farm advice and where appropriate regulation, and assessing the efficacy of mitigation measures.

\section{Acknowledgements}

This paper arises from research funded by the UK Department for Environment, Food and Rural Affairs (Defra) and was carried out under project PE0120. We acknowledge the help of Patricia Butler (North Wyke Research) for her support in the field and towards establishing flow records. Caroline Eliot-Laize and John Griffin (Centre for Ecology and Hydrology, Wallingford) are thanked for laboratory assistance and help in editing illustrations, respectively. We also acknowledge David Haines of Varian Inc. for instructions and guidance regarding the instrument correction procedure for the Varian Cary Eclipse fluorescence spectrophotometer. Useful comments on an earlier draft were received from Daniel Lapworth (British Geological Survey, Wallingford).

\section{References}

Armstrong AC, Garwood EA. Hydrological consequences of artificial drainage of grassland. Hydrol Processes 1991:5:157-74. doi:10.1002/hyp. 3360050204.

Baker A. Fluorescence excitation-emission matrix characterization of some sewageimpacted rivers. Environ Sci Technol 2001;35:948-53.

Baker A. Fluorescence properties of some farm wastes: implications for water quality monitoring. Water Res 2002;36:189-95.

Baker A, Inverarity R. Protein-like fluorescence intensity as a possible tool for determining river water quality. Hydrol Processes 2004;18:2927-45.

Baker A, Spencer RGM. Characterisation of dissolved organic matter from source to sea using fluorescence and absorbance spectroscopy. Sci Total Environ 2004;33: 217-32.

Bilotta GS, Brazier RE, Haygarth PM. The impacts of grazing animals on the quality of soils, vegetation and surface waters in intensively managed grasslands. Adv Agron 2007;94(6):237-80.

Bilotta GS, Krueger T, Brazier RE, Butler P, Freer J, Hawkins JMB, et al. Assessing catchment-scale erosion and yields of suspended solids from improved temperate grassland. J Environ Monit 2010;12:731-9.

Blough NV, Zafiriou OC, Bonilla J. Optical-absorption spectra of waters from the Orinoco River outflow - terrestrial input of colored organic-matter to the Caribbean. J Geophys Res Oceans 1993;98:2271-8.

Boorman DB, Hollis JM, Lilly A. Hydrology of soil types: a hydrologically based classification of the soils of the United Kingdom. Wallingford: Institute of Hydrology Natural Environment research Council; 1995.

Bowes MJ, Hilton J, Irons GP, Hornby DD. The relative contribution of sewage and diffuse phosphorus sources in the River Avon catchment, southern England: implications for nutrient management. Sci Total Environ 2005;344:67-81.

Coddington JA. Problems arising from sheep dipping in England and Wales: a National Rivers Authority view. Scotland and Northern Ireland Forum for Environmental Research, Sheep-dip seminar, 11 November 1992, Perth Scotland; 1992.

Cooper CM. Biological effects of agriculturally derived surface water pollutants on aquatic systems - a review. J Environ Qual 1993;22:402-8.

Dunbar M, Murphy J, Clarke R, Baker R, Davies C, Scarlett P. Countryside Survey: headwater streams report from 2007. Technical Report No. 8/07 NERC/Centre for Ecology \& Hydrology (CEH Project No. C03259); 2010. 67 pp. 
Edwards DR, Daniel TC. Runoff quality impacts of swine manure applied to fescue plots. Trans ASAE 1993;36(1):81-6.

Edwards AC, Hooda PS. Farmyard point discharges and their influence on nutrient and labile carbon dynamics in a second order stream draining through a dairy unit. J Environ Manage 2008;87(4):591-9.

Edwards AC, Kay D, McDonald A, Francis C, Watkins J, Wilkinson RJ, et al. Farmyards, an overlooked source for highly contaminated runoff. J Environ Manage 2008;87(4):551-9.

European Commission. Directive 2000/60/EC of the European Parliament and of the Council of 23rd October 2000 establishing a framework for community action in the field of water policy. Official Journal 22nd December 2000 L327/1. Brussels: European Commission; 2000.

Furse MT, Winder JM, Symes KL, Clarke RT. The faunal richness of headwater streams. A review of existing informationInstitute of Freshwater Ecology Report to the National Rivers Authority, R\&D Project 242, publication reference P-96; 1991.

Galapate RP, Baes AU, Ito K, Mukai T, Shoto E, Okada M. Detection of domestic wastes in Kurose River using synchronous fluorescence spectroscopy. Water Res 1998;32: 2232-9.

Granger SJ, Bol R, Butler PJ, Haygarth PM, Naden PS, Old GH, et al. Processes affecting transfer of sediment and colloids, with associated phosphorus, from intensively farmed grasslands: tracing sediment and organic matter. Hydrol Processes 2007;21:417-22.

Granger SJ, Hawkins JMB, Bol R, White SM, Naden PS, Old GH, et al. High temporal resolution monitoring of multiple pollutant responses in drainage from an intensively managed grassland catchment caused by a summer storm. Soil Water Air Pollut 2010;205(1-4):377-93.

Green FHW. Field drainage in Europe: a quantitative survey, report no. 57. Wallingford: Institute of Hydrology; 1979.

Henderson RK, Baker A, Murphy KR, Hambly A, Stuetz RM, Khan SJ. Fluorescence as a potential monitoring tool for recycled water systems: a review. Water Res 2009;43:863-81.

Holbrook RD, DeRose PC, Leigh SD, Rukhin AL, Heckert NA. Excitation-emission matrix fluorescence spectroscopy for natural organic matter characterization: a quantitative evaluation of calibration and spectral correction procedures. Appl Spectrosc 2006;60:791-9.

Holland JF, Teets RE, Kelly PM, Timnick A. Correction of right-angle fluorescence measurements for the absorption of excitation radiation. Anal Chem 1977;46:706-10.

Hooda PS, Edwards AC, Anderson HA, Miller A. A review of water quality concerns in livestock farming areas. Sci Total Environ 2000;250:143-67.

Hudson N, Baker A, Reynolds D. Fluorescence analysis of dissolved organic matter in natural, waste and polluted waters - a review. River Res Appl 2007:23:631-49.

Hudson N, Baker A, Ward D, Reynolds DM, Brunsdon C, Carliell-Marquet C, et al. Can fluorescence spectroscopy be used as a surrogate for the Biochemical Oxygen Demand (BOD) test in water quality assessment? An example from South West England. Sci Total Environ 2008;391:149-58.

Jarvie HP, Withers PJA, Bowes MJ, Palmer-Felgate EJ, Harper DM, Wasiak K, et al. Streamwater phosphorus and nitrogen across a gradient in rural-agricultural land use intensity. Agric Ecosyst Environ 2010;135:238-52.

Kay D, Crowther J, Fewtrell L, Francis CA, Hopkins M, Kay C, et al. Quantification and control of microbial pollution from agriculture: a new policy challenge? Environ. Sci Policy 2008; $11: 171-84$

Krueger T. Uncertainties in modelling agricultural phosphorous transfers, PhD Thesis, Lancaster University, 2009.

Krueger T, Quinton JN, Freer J, Macleod CJA, Bilotta GS, Brazier RE, et al. Uncertainties in data and models to describe event dynamics of agricultural sediment and phosphorus transfer. J Environ Qual 2009;38:1137-48.

Krueger T, Freer J, Quinton JN, Macleod CJA, Bilotta GS, Brazier RE, et al. Hydrological model hypothesis testing using imprecise spatial flux measurements. In: Tate $\mathrm{NJ}$ Fisher PF, editors. Ninth International Symposium on Spatial Accuracy Assessment in Natural Resources and Environmental SciencesLeicester: University of Leicester; 2010. p. $145-8$.
Lakowicz JR. Principles of fluorescence spectroscopy. New York: Plenum Press; 1983. Lawaetz AJ, Stedmon CA. Fluorescence intensity calibration using the Raman scatter peak of water. Appl Spectroscopy 2009;63:936-40.

Lapworth DJ, Gooddy DC, Allen D, Old GH. Understanding groundwater, surface water, and hyporheic zone biogeochemical processes in a Chalk catchment using fluorescence properties of dissolved and colloidal organic matter. J Geophys Res 2009;114 doi:10.1029/2009JG000921. G00F02.

Levine SL, Schindler DW. Phosphorus, nitrogen and carbon dynamics of experimenta lake 303 during recovery from eutrophication. Can J Fish Aquat Sci 1989;46:2-10.

Maran D, Osborn TJ, Gillet NP. United Kingdom daily precipitation intensity: improved early data, error estimates and an update from 2000 to 2006. International Journal of Climatology 2008;28:833-42. doi:10.1002/joc.1672.

McKnight DM, Boyer EW, Westerhoff PK, Doran PT, Kulbe T, Anderson D. Spectrofluorometric characterisation of dissolved organic matter for indication of precursor organic material and aromaticity. Liminology and oceanography 2001;46:38-48.

Naden PS, Old GH, Eliot-Laize C, Granger SJ, Hawkins J, Bol R, et al. Assessment of natural fluorescence as a tracer of diffuse agricultural pollution from slurry amendment of intensively-farmed grasslands. Water Res 2010;44:1701-12.

Neal C, House WA, Jarvie HP, Neal M, Hill L, Wickham H. Phosphorus concentrations in the River Dun, the Kennet and Avon Canal and the River Kennet, southern England. Sci Total Environ 2005;344:107-28.

Ohno T. Fluorescence inner-filtering correction for determining the humification index of dissolved organic matter. Environ Sci Technol 2002;36:742-6.

Ohno T, Bro R. Dissolved organic matter characterisation using multiway spectral decomposition of fluorescence landscapes. Soil Sci Soc Am J 2006;70:2028-37.

Old GH, Leeks GJL, Packman JCP, Smith BPG, Lewis S, Hewitt EJ, et al. The impact of a convectional summer rainfall event on river flow and fine sediment transport in a highly urbanised catchment: Bradford, West Yorkshire. Sci Total Environ 2003;314-316: 495-512.

Page T, Haygarth P, Beven K, Joynes A, Butler T, Keeler C, et al. Spatial variability of soil phosphorus in relation to the topographic index and critical source areas: sampling for assessing risk to water quality. J Environ Qual 2005;34:2263-77.

Robinson M, Armstrong AC. The extent of agricultural field drainage in England and Wales 1971-1980. Trans Inst Br Geogr 1987;13:19-28.

Smith KA, Jackson DR, Pepper TJ. Nutrient losses by surface run-off following the application of organic manures to arable land. 1. Nitrogen. Environ Pollut 2001;112: 41-51.

Sobczak WV, Findlay S. Variation in bioavailability of dissolved organic carbon among stream hyporheic flowpaths. Ecology 2002;83(11):3194-209.

Tyson KC, Garwood EA, Armstrong AC, Scholefield D. Effects of field drainage on the growth of herbage and the liveweight gain of grazing beef cattle. Grass and Forage Science 1992;47:290-301.

Westerman PW, Overcash MR. Short-term attenuation of runoff pollution potential for land-applied swine and poultry manure. In: Smith RJ, editor. Livestock waste: a renewable resource, proc. 4th Int. Symp. On Livestock Wastes. St Joseph, MI: ASAE; 1980. p. 289-92.

Wetzel RG. Limnology: lake and river ecosystems. San Diego, California, USA: Academic 2001.

Wilkins RJ. The permanent grassland division at North Wyke. Hurley: The Grassland Research Institute; 1982

Withers PJA, Bailey GA. Sediment and phosphorus transfer in overland flow from a maize field receiving manure. Soil Use and Management 2003;19:28-35.

Withers PJA, Jarvie HP. Delivery and cycling of phosphorus in rivers: a review. Sci Total Environ 2008:400:379-95.

Withers PJA, Ulen B, Stamm C, Bechmann M. Incidental phosphorus losses - are they significant and can they be predicted? J Plant Nutr Soil Sci Z Pflanzenernahr Bodenkd 2003;166:459-68.

Withers PJA, Jarvie HP, Hodgkinson RA, Palmer-Felgate EJ, Bates A, Neal M, et al. Characterisation of phosphorus sources in rural watersheds. J Environ Qual 2009;38: 1998-2011. 